\title{
Study on the Status of Network Lending Platform Development of Lujinsuo
}

\author{
Yunlei Huo ${ }^{1, \text { a }}$ \\ ${ }^{1}$ Jilin Business and Technology College, Changcun, Jilin, 130507 \\ a email
}

Keywords: Lujinsuo, Network Lending Platform, Development Status

\begin{abstract}
In recent years P2P network lending emerging as a credit model. This mode is selected by the Internet credit lending platform completed both lending financial transactions, signing a contract, information sharing and other related operations. With financial innovation, P2P network lending industry has been developing rapidly, while its early stage of development exists the problem of risk control and supervision of operations and other aspects still need to analyze and solve. This article Lujinsuo network lending platform, for example, through the introduction of its existing products, the development model and profitability, reflecting the problems they face in the process of development and regulatory risk, aims to explore the domestic financial environment and an adaptation network Credit industry status of net loan business operating models and regulatory mechanisms to promote the steady and healthy development of P2P network lending industry.
\end{abstract}

\section{The Problems in the Development of Lujinsuo Network Lending Platform}

Network technology risk and information security risk is the main risk Lujinsuo network network lending platform facing. From P2 P Network show authentication information point of view, only $11.4 \%$ of the sites that use HTTPS secure hypertext transfer protocol, and uses SSL encryption in data transmission. Because of P2P industry in its infancy, limited capital and technology companies led to a lack of emphasis on P2P network technology risk. Lujinsuo site Most software systems to third-party software company responsible for the level of risk and vulnerability of its system operation is difficult to grasp, some network P2P software companies and between companies at low transparency, the same version of the software application P2 P net loan in a number of companies to reduce operating costs for profit. This allows P2P there is a general security vulnerabilities. Hacking is a major factor leading to the risk of network technology. Inadequate security systems in the industry coupled with the prevalence of software vulnerabilities, greatly increases the likelihood of a hacker attack P2P technology companies. P2P companies in full knowledge of the conditions, the virus can hacking the transaction information, assets, trading process between the two sides leaked to the outside world, to customers and P2P bring incalculable loss.

On the other hand, the customer's information security can not be better protected. Currently Lujinsuo risk control system also needs to improve. Zhang customers before Lujinsuo trading with each other, you need to register an account real-name system certification fill in identity information, credit history and other family composition and content related to personal privacy, this account will reflect all transactions Zhang. Thus the site once the information security risk occurs, the system loopholes or hacked, this information will be Zhang's sale and use to criminals, to bring their own loss of life and economic problems. Zhang and once late payments, the transaction information will be included in the exposure or network communications platform P2P blacklist, so Zhang honor and dignity have been seriously threatened. Information security can not be better protected, hacking computer systems or other means to attack P2P net loan company or network-based customers, will bring losses to net loan credit resources and other aspects of the property. Convenient and efficient online trading platform is a major highlight of P2P net loan industry, if the network technology and information security can not be guaranteed, the development of P2P industry will be difficult. 
Network lending platform lower than the bank compared to the threshold, more efficient, and yet there is no perfect mechanism for customer identification and suspicious transaction reporting mechanism analysis, money laundering has not yet taken seriously, which makes P2P net loan platform become outlaws money laundering " fertile soil. " Such as money launderers Zhao forged by good qualification record by P2P net loan platform audit, and then market their illegally acquired property into a large number of small assets, and then batches lend the borrower, lender of last resort due for repayment, Zhao funds will recover black money "whiten", legalizing illegal. Our financial sector is still the current Internet, "Anti-Money Laundering Law" blind spot, and on the network of economic crime also legal system is not perfect, P2P network lending platform there is considerable risk of being exploited by money launderers.

Legal or policy changes that may affect the development of P2P industry. At present, some P2P industry model of development is not only the surface of financial intermediation, involving financial financing, even illegal fund-raising reach beyond the scope prescribed by law may give the public property and the interests of harm. And because our legal system is imperfect in this regard, these acts are P2P lending platform in China at Present law blind spot. So now P2P industry on the controversial legitimacy.

Liquidity risk is the biggest risk facing the company's net loan. Causes liquidity risk associated with the risk substantially the same. Lujinsuo net loan fully secured platform for investors to invest in principal and interest, the transfer of risk from the investor to be transferred to net loan platform, if the platform itself bad debt leverage more than 10 times, when the borrower fails to repay, net loan platform will Lujinsuo will exceed its own solvency, illiquidity makes poor platform operators facing bankruptcy.

\section{Lending Platform Development Strategies for Lujinsuo}

Our P2P market is still in early stages of development, the necessary integration of advanced information technology and data mining technology is not mature enough. Rely on networking platform between financing and borrowers only, so that they accept the extreme asymmetry of information. Accuracy and completeness of the data is actually more important than the assessment methods, so the domestic P2P net loan platform universal commitment for the next line of the borrower due diligence work, especially to provide risk services platform. Line under a lot of due diligence and credit analysis services can reduce the risk of bad debts, so the introduction of professional and technical personnel, improve the accuracy of the survey and analysis, P2P is a prerequisite for the development of the industry while maintaining stability.

Implement flexible regulatory principles. Faced with financial innovation internet on P2P net loan industry regulators should be more flexible, with flexibility. For emerging P2P industry, the initial specification should guide their development and take appropriate risk tolerance principle to achieve inclusive development does not touch the bottom line basis. Therefore, to ensure that the overall risk does not affect the financial order and financial stability, based on the risk tolerance range can be appropriately adjusted, encourage industry self-regulation, a government regulation, supplemented by regulatory policy. The flexible regulatory principles, the Government should be adjusted according to the latest changes P2P timely regulatory measures to avoid over-regulation inhibits innovation, in order to achieve both promote the healthy development of the internet and to avoid the potential risk of a double target.

Strengthen self-discipline and association rights. With respect to the external supervision ten pre-industry self-regulation through self-monitoring and constraints more efficiently regulate and guide the development of the whole industry. Regional and national self-regulatory organization of P2P industry only gradually formed the core of the current priorities is to increase transparency in the sector. In addition, as still in the formative years of the new industry, P2P industry self-regulation to promote the industry while still taking into account the development dimension. First, the establishment of influential industry self-regulatory body, the use of credit information sharing mechanism and sharing platform, monitoring and supervision of risk warning and moral oversight function transactions, thereby increasing the level of business risk control. 
The introduction of risk rating agency mechanism. Specification P2P net loan platform in addition to capital requirements, policy sector should consider P2 P net loan risk rating agency platform, timely disclosure of information to the community rating, specifications P2P net loan market. But also through fiscal policy, risk warning window guidance, registration and supplementary capital requirements and investor protection policies and improve the institutional risk control system.

The establishment of platform security index system. For client information confidential, we can proceed in terms of the establishment of internet security index system, improve the professional quality of employees and so on. P2P platform to our customers related to economic assets, serious, will endanger the entire financial system and social order. Therefore, we must accelerate the construction of information security system, so that each investor can choose the high level of information security platform, forcing the platform to improve their professional quality and management level through survival of the fittest mechanism. Ministry of Public Security should be based on standards in information security requirements for information security platform to assess the extent of P2P classification. Through the platform level security technology to prevent protective measures, safety records and other party and to analyze, evaluate, reflect the build platform security index system. If you encounter a malicious intrusion and theft, P2P platform should take the initiative and actively alarm record restoration platform vulnerabilities, and protect the legitimate rights and interests when the platform with customers.

Established secondary market. P2P net loan industry, like the stock market, we need to reduce the risk of a secondary market. Secondary market existing domestic P2P net loan industry is actually an internal platform for the transfer of claims, and both lenders and borrowers changed, so the secondary market is not in the true sense. P2P industry needs to accommodate a whole industry, and there is a mechanism to help organize investors to investment, optimize investment portfolio, to avoid the risks of trading in the secondary market. Let assisted P2P net loan secondary market platform to reduce risk and healthy development.

\section{References}

[1] First Financial Research Center on Chinese lending services industry P2P White [M]. Beijing: China Economic Publishing House, 2015.

[2] Fu Xinying. Thoughts on the Development of P2P network lending industry [J]. Business, 2013 (12).

[3] Li Yaodong, Lee Kwan Internet financial framework and practice of [M]. Beijing: Electronics Industry of the community .2015. 